DOI: 10.46340/ephd.2020.6.4.10

\author{
Natalia Chumak \\ ORCID ID: https://orcid.org/0000-0003-1522-7817 \\ V. N. Karazin Kharkiv National University, Ukraine
}

\title{
MODERN MALLEABLE CULTURAL FORMS AS A REFLECTION OF HUMAN SELF-EXPRESSION
}

\author{
Наталія Чумак \\ Харківський національний університет імені В.Н. Каразіна, Україна
}

\section{СУЧАСНІ ПЛАСТИЧНІ КУЛЬТУРНІ ФОРМИ ЯК ВІДОБРАЖЕННЯ САМОВИРАЖЕННЯ ЛЮДИНИ}

\begin{abstract}
Plastic culture as a cultural and anthropological phenomenon is a dynamic philosophy of its era. Crisis phenomena in modern and postmodern culture was illustrated by plastic culture. The loss of integrity in the "spirit - soul - body" trinity and self-perception forces modern artists to look for ways to regain human self-expression and find themselves. The modern plastic language of art testifies to the search for self-expression and misunderstanding, internal duality, which are caused by ambiguous political processes in Ukrainian society, the transformation of moral and ethical values and the decline of the spiritual and aesthetic component of the consciousness of a human-consumer.

This article offers bodily models of self-expression for consideration, such as inclusive dance, Pina Bausch Dance Theater, modern dance trends as a means of reproducing a harmonious selfperception and overcoming the alienation of the body through plastic self-expression. Plastic self-expression of the social body and the everyday body, as well as the renovation of the body's memory, play a significant role in restoring the disturbed worldview and overcoming loneliness. Postmodern plastic culture, therefore, allows us to overcome the trauma of the totalitarian era through modern bodily practices, when the body did not belong to itself, but was a part of the social controlling body. Modern plastic forms of self-expression allow us to solve problems of both a social nature (relieving tension in relationships, overcoming intergroup social conflicts) and a personal nature (self-knowledge, overcoming internal conflicts and loneliness, restoring integrity).
\end{abstract}

Keywords: plastic culture, plastic cultural form, plastic self-expression, social body, everyday body, modern dance, inclusive dance.

Інформаційна перенасиченість культурного простору впливає на пластичну мову сучасного мистецтва і вносить в нього такі явища, як дисонанс, дисгармонія, деформація, реконструкція, алогічність, абсурд і т. д.

Пластична мова сучасного мистецтва відображає внутрішні процеси самовідчуття людини, а саме відчуженість від тіла, проблема смерті та швидкоплинності життя, невпевненість у собі та страх перед оточуючою дійсністю, знецінення людського життя та перетворення людини на річ або товар. Сучасні культурні практики, що відбуваються у публічному просторі, можуть допомогти не тільки привернути увагу до проблематики пластичної мови. Будучи форматом роботи з травмою, як втрата можливості репрезентації світогляду через тіло, саме культурні студії можуть повернути тіло людині. У даній статті пропонуються культурно-антропологічні моделі сучасного мистецтва, які відображають самовираження людини через пластичні форми, що сприяють відтворенню цілісності само сприйняття та подоланню відчуженості тіла.

Пластичне самовираження людини як культурно-антропологічний феномен можна розглянути в контексті «соціального тіла». Сучасне мистецтво і культура завжди шукають і знаходять шляхи повернення самовідчуття людини через ії тілесність та пластичне самовираження.

Так, показовим у цьому сенсі є танцтеатр Піни Бауш, започаткований у 70-ті рр. минулого століття. Актуальний і зараз, цей театр відкриває людині нові технічні інструментарії сповіді 
через соціальний публічний простір. Самі акти висловлювань відбуваються не тільки як протест, але й як покаяння.

Творчість Піни Бауш унікальна тим, що ï називають найвільнішим художником і митцем після війни, яка вільна від будь-яких умовностей та систем, крім пам'яті трагічного минулого 40-pp. XX ст. ${ }^{1}$ Актори її танцтеатра завдяки самовираженню себе через пластику говорять 3 глядачем на зрозумілій їм мові руху, де тіло стає інструментом багатозвучним і набагато виразнішим, ніж слово. Повернення до себе, самопізнання своїх внутрішніх конфліктів у танці-спектаклі Піни Бауш стає потоком пізнання; відбувається відкриття власного «Я» через діалог з навколишнім світом. Цей діалог формується не стільки у середині самого танцю 3 партнерами, з синхронізованими (а частіше, розсінхронізованими) рухами, скільки зі звичними об'єктами публічного простору (потяг, промислова вулиця, стільці, дощ тощо). Внутрішня занепокоєність, бажання вирватися з міжособистісних стосунків, утеча від проблем виводять танцора за межі театру у звичайний ритм соціального життя. Актор, немов стає подразником встановлених соціальних стосунків, який намагається зупинити ритміку сучасних норм та правил алютьюсерівським криком «Ей, ти!». Готовність принести себе у жертву заради зміни встановленої матриці стосунків майже завжди у кінці танцю обертається трагедією. Але сам глядач опиняється у стані сублімації, оскільки багато що вже за нього сказано через танець. Відбувається знаходження себе і повернення людини до свого початкового гармонійного стану. На прикладі творчості Піни Бауш можна стверджувати про позитивні процеси сучасного мистецтва, спрямовані на створення нового пластичного образу сучасної людини, вільної від соціального тиску, здатної до самовираження та саморозкриття свого внутрішнього світу, що не віддаляє іiї від соціума, а завдяки самоосмисленню дозволяє їй бути більш чутливою до інших. Танець як потік пізнання стає тією сходинкою знаходження втраченої цілісності між тілом та пізнанням. Оптимістичним явищем у творчості Піни Бауш стає динаміка ії поглядів, які знаходять вираження в її постановках, від трагізму та депресії до повноти життя і прояву радості.

Функція культури в інформаційному суспільстві стає неоцінимою як засіб гармонізації суспільних відносин і зняття напруги у відносинах «я - інший».

Ще одним прикладом формування здорового гармонійного соціального тіла $є$ інклюзивний танець. Це достатньо новий засіб пластичного самовираження людей з обмеженими фізичними здібностями, інвалідів. Завдяки танцю вони включаться в соціальне життя під гаслом: «У житті ми різні, у танці- рівні». Фестивалі інклюзивного танцю привертають увагу соціуму до людей, які потребують уваги та бажають жити повноцінним життям, сприяють формуванню толерантності у суспільстві, милосердя та оздоровлюють суспільні відносини.

Людина, нездатна поринути у світ звуку, може стати зрозумілою іншим через рух, пластику, що дозволяє їй виразити себе як повноцінну духовну, інтелектуальну особистість. Інклюзивний танець між здоровою людиною та інвалідом стає мостом, який зближає та взаємно збагачує людей.

Танець стає тим терапевтичним засобом для суспільства конс'юмерів, який долає кордони страху перед соціумом, лікує травму непорозуміння, залишеності та неповноцінності. Емоції радості, туги зближують людей в єдиному культурному просторі, сприяють формуванню близьких відносин, дружби. Таким чином, танець стає засобом інтеграції людей з обмеженими фізичними можливостями в соціум.

Параолімпійські ігри виконують подібну функцію. Спорт виходить за рамки комерціалізації і стає на службі людяності та співчуття. Відомий випадок, коли легкоатлети-параолімпійці прийшли до фінішу всі разом, щоб не кинути свого колегу, який упав на біговій доріжці.

Фізична неміч людини стає іiї силою, коли мають місце високі моральні та духовні якості.

Важливим, на наш погляд, є поява екстремальних видів спорту, таких як аквабайк (гонки на гідроциклах), вінденсерфінг (гонки на парусних дошках), дайвінг (понурення у воду з аквалангом), дельтапланеризм (політ на дельтаплані), зорбінг (спуск упрозорій кулі з верхівки), каньйонінг (подолання річних каньйонів без плаваючих засобів), маунтинбайк (спуск з гори на спеціальному велосипеді), спелеотуризм (спортивний туризм, пов'язаний з подоланням печер); паркур (швидкісне переміщення та подолання перешкод із використанням елементів стрибка) та інші. Екстремальні види спорту пов'язані з загрозою для життя, і все ж таки вони мають багато прихильників. Чим можна пояснити таку трансформацію? Перш за все, на наш погляд, це виклик самому собі і тій системі соціального контролю над тілом, яка сформувалась у період модерну. Ми маємо справу з симулякром

\footnotetext{
${ }^{1}$ Бауш, Пина (2012). Современная хореография. Культура и искусство <http://cult-and-art.net/dance/233-pina_ baush_pina_bausch_sovremennaja_horeografija> (2020, листопад, 12).
} 
Бодріяйра: «все перетворюється у свою протилежність, щоб увіковічити себе у відкоректованому вигляді». ${ }^{1}$ Граючи зі смертю, людина намагається оживити своє тіло, вивести його зі стану сомнамбулічного сну та завмерлого кокона. Лавіруючи на грані життя та смерті, людина починає розуміти ціну життя і відчувати його смак. Завідуючий кафедри психології у Гарварді Антоніо Дамасіо вважає, що «основою нашого самопізнання $€$ фізичні відчуття, які передають внутрішній стан тіла» i далі розвиваючи його думку Б. ван дер Колк стверджує, що первісні почуття дозволяють напряму відчути наше живе тіло, без слів та прикрас, пов'язане з самим нашим існуванням. Ці первісні почуття відображають існуючий стан тіла у різних вимірах ... по шкалі від задоволення до болю і зароджуються вони на рівні стовбура мозку, а не кори великих полу куль». ${ }^{2}$ Тобто для того, щоб відчути себе живою, людині треба відродити почуття свого тіла, навіть через біль та страх втрати життя. Таким чином, ми бачимо, що сучасні види екстремального спорту змінюють пластичну культурну форму, яка була створено спортивною індустрією епох модерну, тоталітаризму та постмодерну. Спорт як комерціалізація стає нецікавим для тих, хто знаходиться у пошуках себе, він не задовольняє потреби відтворення цілісності та повернення повноти життя і відчуття живого тіла.

Окремо хотілось звернути увагу на паркур та його філософію. Трейсери (ті, хто займаються паркуром) не вважають цей вид фізичної активності спортом, адже вважають, що змагання, яке присутнє у спорті, обмежує свободу. Філософія паркура - це, перш за все, подолання труднощів себе, супротивника, страхів, невпевненості, перешкод - усього того, що стримує саморозвиток і самовдосконалення. Трейсери демонструють надзвичайні можливості руху i тіла в умовах урбанізації. Паркур - це виклик міській культурі, замкненій у кордони пішохідних доріжок, високих стін будівель, автомобільних магістралей. Використовуючи стрибки по дахам та вузьким перилам, стрімкий рух по укісній стіні, трейсери порушують механічний рух міського натовпу, виводять його зі стану буденності. Основним засобом такого незвичайного руху є саме тіло без допоміжних засобів, яке демонструє величезний потенціал руху і свідчить про свою досконалість без технічних пристроїв. Це виклик мертвості міського механічно існування, техніці та тілу-машині. Це нова філософія нового пластичного самовираження людини інформаційного сучасного суспільства, яка повертає відчуття цілісності та повноти життя.

Стрімкий науково-технічний прогрес $\mathrm{i}$ формування нового інформаційного простору 3 наявністю невід'ємної його частини - гаджетів, все більше роблять значним розрив і непорозуміння поколінь. I як раніше, коли молодь виступила проти пережитків тоталітарних режимів, травми війни формуванням молодіжних субкультур хіпі, панків, рокерів, так і зараз виникають нові молодіжні культурні напрямки, спрямовані на привертання уваги старшого покоління, виходу накопиченої агресії та сублімативної енергії.

3'являються нові форми пластичного самовираження у танці, як нова пластична культурна мова і засіб спілкування та само презентації.

Напрямок хіп-хоп у танцювальній маскультурі $\epsilon$ засобом молоді розповісти про себе не стримуючи себе у пластичному самовираженні, це вільний танець, який увібрав у себе багато напрямів вуличних танців і став візитною карточкою сучасної «нестандартної» молоді.

Стиль танцю «терфінг» виник як прояв протесту проти утисків чорношкірого населення американських штатів. Через динамічні агресивні і механічні рухи танцюристи виражають форму протесту проти незаконних дій поліції, свою внутрішню агресію вони сублімують у танець і таким чином знімають напругу.

Танець у стилі «крамп» теж породження американської маскультури. Основним призначенням цього стилю стало зняття напруги у молодіжних стосунках різних районів американських штатів i переростання вуличних бійок у танцмарафон. Досить вдала форма сублімації через рухову активність як заміна відсутності інтелектуальної чи духовної світоглядної функції. Не можна сказати, що танець у цьому випадку сприяє відродженню цілісності самосприйняття, але в усякому разі він виконує терапевтичну роль і повертає людину до осмислення себе і викриття внутрішніх конфліктів.

Прискорений темп життя міняє ходу людини. Сучасна людина постійно поспішає, тому одяг i взуття стають все більш практичними; модним є спортивний стиль для різних вікових категорій.

\footnotetext{
${ }^{1}$ Жан, Б. (1981). Симулякры и симуляція. Livelib <https://www.livelib.ru/book/1001127725-simulyakry-i-simulyatsiizhan-bodrijyar> (2020, листопад, 12).

${ }^{2}$ Бессел, В. д. К. (2020). «Тело помнит все. Какую роль психологическая травма играет в жизни человека и какие техники помогают ее преодолеть. Mybook <https://mybook.ru/author/bessel-van-der-kolk-2/telo-pomnit-vsekakuyu-rol-psihologicheskaya-travm/read/> (2020, листопад, 12).
} 
Свобода руху, поз у суспільних місцях свідчать про формування нового розкутого пластичного самовираження, іноді до проявів девіації. Вихід за рамки зразкового соціального тіла, утвореного в часи тоталітарних режимів, відбувається на рівні тіла буденного.

Важливу роль у рефлексії відіграє ефект пам'яті тіла. Тіло, яке з часом втрачає гнучкість та активність, зберігає цю інформацію на рівні генетичної пам'яті. Навик тіла (па балерини, техніки спортивної гімнастики, тощо), привласнений за часів його активності, записується в пам'яті тіла і стає провідником між минулим та сучасним, між діяльністю та нерухомістю. Пам'ять м'язів, ніг, рук відкриває вікно у минуле, де людина почувала себе здоровою та активною і це сприяє одужанню, повертає радість та надію. Однією з сучасних терапевтичний практик у роботі з людьми похилого віку є практика пам'яті тіла через музику, згаданий образ, театр. Культурно-антропологічний феномен пластичного самовираження тіла буденного через пам'ять тіла стає важливою складовою у відновленні порушеного світосприйняття, подолання самотності.

Пам'ять тіла здатна викликати почуття вже пережитих подій, які можуть відтворити ментальну пам'ять; для терапевтичного ефекту важливо, щоб вона не була пов'язана з біллю та душевним потрясінням. Пам'ять тіла, на думку Р. Козеллека, це переживання, яке зберігається завдяки рутинізації. А. Лінченко вважає, що «тілесна пам’ять уявляю собою особливу цілісність, рухому єдність біологічної, автобіографічної та соціальної пам'яті» ${ }^{1}$. Тому пам'ять тіла можна розглядати в якомусь сенсі як історичний документ, як пам'ятку пережитої епохи, відображеної в пластичній мові тіла.

Про тіло буденне та пам'ять тіла говорив М. де Серто. «Жести - справжні архіви міста, якщо тільки розуміти під "архівами" минуле, яке обирається і використовується заново відповідно до звичаїв сьогодення.... ${ }^{2}$

Реновація пам'яті тіла може, таким чином, бути корисною для сучасного переживання та осмислення себе через пластичне самовираження.

Таким чином, різні форми пластичної культури у сучасному мистецтві, такі як танцтеатр Піни Бауш, постмодерні танцювальні напрямки, інклюзивний танець, екстремальні види спорту не тільки викривають проблеми сучасного суспільства-конс'юмерів, але і пропонують вирішення цих проблем шляхом пластичного самовираження, внаслідок чого відбувається подолання відчуженості від тіла, гармонізація внутрішнього стану людини.

\section{References:}

1. Bausch, P. (2012). Sovremennaya khoreografiya [Contemporary choreography]. Kultura i iskusstvo [Culture and art.] 〈http://cult-and-art.net/dance/233-pina_baush_pina_bausch_sovremennaja_horeografija〉 (2020, November, 12). [in Russian].

2. Jean, B. (1981). Simulyakry i simulyatsiya [Simulacra and simulation]. Livelib <https://www.livelib.ru/book/1001127725-simulyakry-i-simulyatsii-zhan-bodrijyar> (2020, November, 12). [in Russian].

3. Bessel, V. d.K. (2020). Telo pomnit vse. Kakuyu rol psikhologicheskaya travma igrayet v zhizni cheloveka i kakiye tekhniki pomogayut yeye preodolet [The body remembers everything. What role does psychological trauma play in a person's life and what techniques help to overcome it]. Mybook $<$ https://mybook.ru/author/bessel-van-der-kolk-2/telo-pomnit-vse-kakuyu-rol-psihologicheskaya-travm/read/> (2020, November, 12). [in Russian].

4. Linchenko, A. A. (2016). Pamyat tela v prostranstve povsednevnoy istoricheskoy kultury: filosofskometodologicheskiy aspekt [Body memory in the space of everyday historical culture: philosophical and methodological aspect]. Vestnik Vyatskogo gosudarstvennogo universiteta [Vyatka State University Bulletin]. Cyberleninka <https://cyberleninka.ru/article/n/pamyat-tela-v-prostranstve-povsednevnoy-istoricheskoy-kulturyfilosofsko-metodologicheskiy-aspekt> (2020, November, 12). [in Russian].

5. de Certeau, M. (2010). Prizraki v gorode [Ghosts in the city]. Zhurnalnyy klub Intelros Neprikosnovennyy zapas [Intelros Magazine Club Emergency Stock] 〈https://magazines.gorky.media/nz/2010/2/prizraki-v-gorode.html〉 (2020, November, 12). [in Russian].

\footnotetext{
1 Линченко, А. А. (2016). Память тела в пространстве повседневной исторической культуры: философско-методологический аспект. Вестник Вятского государственного университета. Cyberleninka <https://cyberleninka.ru/article/n/pamyat-tela-v-prostranstve-povsednevnoy-istoricheskoy-kultury-filosofskometodologicheskiy-aspekt> (2020, листопад, 12).

2 де Серто, М. (2010). Призраки в городе. Журнальный клуб Интелрос Неприкосновенный запас, 2

<https://magazines.gorky.media/nz/2010/2/prizraki-v-gorode.html> (2020, листопад, 12).
} 